\title{
Effect of Inquiry Learning Strategies on Student Discrete Mathematics Learning
}

\author{
Nuke Lu'Lu Ul Chusna $\mathrm{S}^{1, *}$, Zulfiati Syahrial ${ }^{2}$, \\ Nurdin Ibrahim ${ }^{2}$, Muhammad Ridha Albaar ${ }^{3}$ \\ ${ }^{1}$ Educational Technology Postgraduate Program, Jakarta State University, Indonesia \\ ${ }^{2}$ Department of Educational Technology, Jakarta State University, Indonesia \\ ${ }^{3}$ Department of Management Information, Academy of Computer Science (AIKOM) Ternate, Indonesia \\ *Corresponding author. Email:nuke.informatika@gmail.com
}

\begin{abstract}
Learning will be effective, if learning activities can achieve goals, that is, students can absorb the learning material and practice it so that they obtain the best competencies and skills. Mathematics is one of the sciences that is able to hone skills and teach students to think critically. Mathematics is a symbolic language that expresses ideas, structures, or logical relationships including abstract concepts. Mathematics is a structured science, because mathematics starts from elements that are not defined for axioms or postulates and finally to theorems. This study aims to obtain a picture of the effect of Inquiry Learning Strategies on student learning outcomes for Discrete Mathematics. It is expected that by using or giving treatment of inquiry learning strategies to students who take discrete mathematics courses learning outcomes will increase.
\end{abstract}

Keywords: inquiry learning strategies, learning outcomes, discrete mathematics

\section{INTRODUCTION}

Education is one aspect of life that plays an important role in facing the challenges of the times and the development of science and technology. So education must be implemented as well as possible to obtain maximum results. Education cannot be carried out without teaching, and vice versa teaching will not be meaningful without the aim of education. Education is a business of personal development as a whole and more concerned with issues of image and values, while teaching is an effort to develop intellectual capacity and various physical skills [1].

Effective learning is not something that is simple or certainly not sufficient anymore if only interpreted as limited to the transfer of knowledge, it is important to be interpreted as constructivist learning that is more oriented towards students (student centries). In a sense, students become the center of learning, while teachinglearning surrounds students [2].

According to the National Education System Law No. 20 of 2003, article 1 paragraph 20 (Ministry of National Education, 2003: 2), learning is the process of interaction of students with educators and learning resources in a learning environment.

To realize effective learning is very dependent on how learners (educators) can develop learning strategies, and can choose the right strategy in implementing learning activities. strategies that must be mastered by educators in conducting learning, are 1). Learning Organizing Strategy, refers to how to make ururtan and synthesize facts, concepts, procedures and related principles, 2). Learning Submission Strategies, deliver learning content to students and provide information needed by students to show performance, 3). Learning Management Strategies, methods related to how to organize interactions between students with other learning methods. This strategy is related to decision making about the organizing strategy and delivery strategy used during the learning process.

Effective learning, if learning activities can achieve the goal that students can absorb learning material and practice it so as to obtain the best competencies and skills.

One of the learning materials that is able to hone students' abilities and teach students critical thinking is mathematics. Mathematics is a symbolic language that expresses ideas, structures, or logical relationships including abstract concepts making it easier for humans to think.

The exact study program requires the support of mastery of mathematics, but in fact many students are not happy with mathematics courses, because they are considered as obstacles to the progress of their studies. In the attention and observation of researchers, there is a tendency that there is no sincerity and excitement, there 
is no absorption of teaching materials properly and correctly. As a result, mathematical material is not mastered properly and correctly, which causes students to not know or use it incorrectly [3].

The role of mathematics instructors as educators, has an important role in transferring their knowledge to students in the learning process, which must make students understand the knowledge and skills provided by teachers to students to solve their own problems in mathematics [4]

Mathematics as a decdutive science, because the process of finding truth (generalization) in mathematics, is different from natural science and other sciences. The truth-seeking method used is the deductive method, where the generalization of the nature, theory or the proposition can be accepted after being proven deductively. Mathematics is an organized structured science, because mathematics starts from elements that are not defined to the axioms or postulates and finally to the theorems. Mathematical concepts are arranged in a hierarchical, structured, logical and systematic manner starting from the simplest concepts to the most complex concepts. Therefore, to study mathematics, the previous concepts that are prerequisites must be mastered in order to understand the next topic or concept [5].

For classroom learning to be effective, teachers must choose the right learning strategy. Learning strategies are the methods chosen by teachers to carry out learning activities [6]. The learning strategies used by teachers must be in accordance with the characteristics of students. In the selection of learning strategies, instructors must pay attention to student characteristics related to the learning styles and intelligence of students. Currently students are still experiencing learning difficulties and do not understand the concept correctly, and this can be seen from the results of student learning.

\section{LITERATURE REVIEW}

\section{a. Learning}

Learning and learning are the main activities carried out in an educational process. Learning activities can be carried out if students are given the opportunity to participate in the learning process, as well as the learning process will run well if students are involved in learning [7].

Golberg (2001) menyatakan belajar adalah beragam proses yang dianggap sesuatu yang biasa oleh individu sampai mereka mengalami kesulitan disaat menghadapi tugas yang kompleks. Akan tetapi belajar adalah kharakteristik yang membedakan manusia dari makhluk lainnya, dan hanya manusia yang memiliki otak yang berkembang baik untuk digunakan melakukan tindakan yang memiliki tujuan [8].
Learning is a variety of processes that are considered something ordinary by individuals until they have difficulty when facing complex tasks.

The nature of learning according to Bloom, is in 1). Cognitive Domain, with regard to intellectual learning outcomes consisting of six aspects including knowledge, understanding, application, analysis, synthesis and evaluation, 2).Affective domain, with regard to attitudes consisting of five aspects including acceptance of answers, judgment, organization and internalization and 3).Psychomotor domains, with regard to learning outcomes in the form of basic motion skills, perceptual abilities, accuracy, skills, and expressive and interpretive movements.

Learning is a process of behavior change, that is, changes related to aspects of knowledge, attitudes and skills [9].

So that it can be said that learning is a process that is due to interactions with the surrounding environment, and happens to everyone throughout his life, can occur anywhere and anytime, can also be said there is a sign of a change in behavior that occurs due to changes in the level of knowledge, skills and attitude.

\section{b. Learning Outcomes}

Learning outcomes are, the learning process which is generally an activity that results in a change in behavior, an understanding of learning undertaken by the instructor in such a way that the student's behavior changes for the better. Student learning outcomes can increase if students' interest in learning in meta-lecture also increases [10].

Classification of learning outcomes from Bloom, divides it into three domains, namely:

a) Cognitive Domain, intellectual learning outcomes consisting of six aspects, namely knowledge, understanding, application, analysis, synthesis and evaluation. The first two aspects (aspects of knowledge and understanding aspects) are called the low level cognitive domain and the last four aspects (application aspects, analytical aspects, synthesis aspects and evaluation aspects) include high level cognitive domains

b) The Affective Domain, regarding attitudes, consists of five aspects namely acceptance, answers or reactions, judgment, organization and internalization

c) Psychomotor domains, regarding the learning outcomes of skills and ability to move there are six aspects namely reflex movements, basic movement skills, perceptual abilities, harmony or accuracy, complex movement skills and expressive and interpretative movements

These three domains are objects of assessment of learning outcomes, and of these three domains the cognitive domain is most valued by a teacher or educator, because it is related to the ability of students to master learning material [11]. 
Student mathematics learning outcomes are still far from expectations, although individual learning achievement is able to reach an optimal level. However, it needs to be improved so that each student can improve his learning achievement. Many factors affect student learning outcomes, such as external factors, including the low physical facilities, the high cost of education, the quality of competent teachers are uneven. The biggest influence remains from internal factors, namely from within the students, physiological factors related to physical conditions and psychological factors, namely matters relating to the mental condition of students. Internal factors that play a role in determining student learning outcomes in education one of which is academic potential.

Said to get increased learning outcomes that mastering learning will improve student learning outcomes in long memories and attitudes towards learning material [12].

\section{c. Inquiry Strategy}

To achieve optimal learning outcomes a learning strategy is needed, where the activities must be arranged, designed and managed in such a way that the learning process.

Learning Strategy is a comprehensive approach to learning in a learning system, in the form of general guidelines and a framework of activities to achieve the general objectives of learning, which are elaborated from the view of certain philosophies and / or learning theories [13]

Dick and Carey stated that the learning strategy explained the general components of a set of learning materials and procedures that would be used with other materials to state the particular learning outcomes of students. Dick and Carey explained the five components of learning strategies namely, 1). Preliminary activities, 2).Submission of Information, 3).Participation from students, 4).Tests, and 5). Follow up activities [14].

Teachers must think of effective and efficient learning strategies in helping students to achieve the expected learning goals.

Inquiry learning emphasizes the process of searching and finding. Students in the inquiry learning strategy is to find and find their own learning material, while the teacher as a facilitator and guide students to learn [2].

Inquiry learning strategy is a learning strategy that can be used in the learning process in the field of science. Inquiry strategy is a series of learning activities that emphasize the process of thinking critically and analytically to look for and find the answers themselves to a problem being asked [6].

The learning strategies applied by discrete mathematics instructors when the learning process has not been centered on students, and the learning process implemented by the instructor has not been centered on students because they still use the lecture method, have never applied mathematics learning with inquiry learning strategies. Student learning outcomes for mathematics learning material is quite low far from the expected value.

To overcome this, is to apply inquiry learning strategies in the process of learning mathematics. In the inquiry learning strategy students play an active role to find and find their own mathematics learning material. The teacher only acts as a facilitator in learning, so that it can encourage students to be more active in the learning process and can achieve the expected learning outcomes [15].

\section{RESULTS AND DISCUSSION}

Increased ability to solve discrete mathematical problems that is by means of students being able to understand problems, plan problem solving, carry out problem solving plans and double check problem solving results.

In improving the ability of problem solving and creativity of discrete mathematics learning, it can be seen from the indicators that have changed, where the problem solving indicator is identifying the elements that are known, asked, and the adequacy of the elements needed, formulating mathematical problems, implementing strategies to solve various, interpreting the results of the problem.

Learning with inquiry learning strategies in problem solving, learning can be done in small groups, so as to grow knowledge, thinking abilities, attitudes and skills. The learning with problem solving can be done through certain stages.

In general, in the learning process by using inquiry learning strategies there are stages that are passed, as follows a). Orientation Stages, the teacher conditions students to be ready to carry out the learning process, invites students to think about how to solve problems, b). Define the Problem, bring students to a problem that requires students to think about solving the problem to be studied, because the problem has an answer, and students are directed to find the right answer. The process of finding answers is very important in inquiry learning strategies, because the process students will gain valuable experience and as an effort to develop mentally through the process of thinking, c). Formulating Hypotheses, hypotheses that appear are rational and logical, which are strongly influenced by the depth of insight they have and the breadth of experience, d). Collecting Data, in inquiry learning strategies, collecting data is a mental process that is very important in intellectual development, e). Hypothesis testing, means developing the ability to think rationally, 
meaning that the truth of the answers given is not only based on argumentation, but must be supported by data found and can be justified, f). Formulating conclusions, is the process of describing the findings obtained based on the results of testing hypotheses, to reach conclusions that are accurate and teachers should be able to show students which data are relevant.

By utilizing inquiry learning strategies can improve student learning outcomes. This can be seen from the increase in students' discrete mathematics scores, although there are still some that are still not optimal in their learning outcomes. This is common because of lack of thoroughness in solving students in solving discrete mathematical problems.

The application of inquiry learning strategy is very appropriate to be applied in discrete mathematics learning, because in this strategy students are required to learn actively and students are also trained for learning in inquiry so that many students are involved in learning and can help students to improve their ability to solve discrete mathematics problem solving.

\section{CONCLUSION}

Inquiry learning strategy is a learning strategy that seeks to instill the basics of scientific thinking in students, so that in the learning process, students learn more by themselves, develop creativity in solving problems, plan experiments, conduct experiments, collect and analyze data, draw conclusions.

Inquiry learning strategies in students can be developed with an objective attitude, honesty, curiosity, openness and so on, and in the end can reach conclusions that are mutually agreed upon.

\section{REFERENCES}

[1] Wala S Y Purnami A S and Widodo S A, 2017 Efektivitas Model Pembelajaran Kooperatif Number Head Together Terhadap Hasil Belajar Matematia XVII, 2 p. 53-66.

[2] Mulyono $\mathrm{H}$ and Wekke I S, 2018 Strategi Pembelajaran di Abad Digital Pertama Jogjakarta: Gawe Buku.

[3] Hamzah, Ali M, 2016 Perencanaan dan Strategi Pembelajaran Matematika Jakarta: PT. RajaGrafindo Persada.

[4] Siregar E and Sirega S R, 2019 Inquiry learning strategy to improve mathematics achievement of junior high school J. Phys. Conf. Ser. 1188, 1.

[5] Hastuti Noer S, 2017 Strategi Pembelajaran Matematika Pertama Jogjakarta: Matematika.

[6] Sanjaya W, 2006 Strategi Pembelajaran Jakarta: Media Prenada.
[7] Sani Abdullah R, 2019 Stretegi Belajar dan Mengajar Editi pert PT. RajaGrafindo Persada.

[8] Gredler M E, 2009 Learning and Instruction Theory into Practice Sixth Edit Pearson Education, Inc.

[9] Karwono and Mularsih H, 2018 Belajar dan Pembelajaran 2nd editio PT. RajaGrafindo Persada.

[10] Putriani D and Rahayu C, 2018 The Effect of Discovery Learning Model Using Sunflowers in Circles on Mathematics Learning Outcomes Int. J. Trends Math. Educ. Res. 1, 1 p. 22.

[11] Sudjana N, 2016 Penilaian Hasil Proses Belajar Mengajar Bandung: PT. Remaja Rosdakarya.

[12] Schunk D H, 2012 Learning Theories an Educational Perspective 6th editio Pearson Education, Inc.

[13] Miarso Y, 2004 Menyemai Benih Teknologi Pendidikan 2nd editio Prenamedia Group.

[14] Dick W Carey L and Carey O C, 2015 The Systematic Design of Instruction Eighth Edi Pearson Education, Inc.

[15] Rokhmah S and Marzuki I, 2018 Pembelajaran Inkuiri pada materi Menghitung Luas Persegi dan Persegipanjang untuk meningkatkan Hasil Belajar Matematika Peserta Didik kelas III SDN 1 Randuangung Gresik JTIEE 2, 2 p. 105-110. 